\title{
OCEANIC DISPERSAL MODEL OF GREEN TURTLE HATCHLINGS IN THE SOUTH CHINA SEA
}

\author{
NADHIRAH SYAFIQAH SUHAIMI ${ }^{1}$, NURUL RABITAH DAUD ${ }^{2}$, MOHD FADZIL AKHIR ${ }^{3}$ \\ and MOHD UZAIR RUSLI ${ }^{3 *}$ \\ ${ }^{1}$ Faculty of Science \& Marine Environment, Universiti Malaysia Terengganu \\ ${ }^{2}$ Faculty of Civil Engineering, Universiti Teknologi MARA, 40450, \\ Shah Alam, Selangor, Malaysia \\ ${ }^{3}$ Institute of Oceanography \& Environment, Universiti Malaysia Terengganu, \\ 21030 Kuala Nerus, Terengganu, Malaysia \\ "E-mail: uzair@umt.edu.my
}

Accepted 7 October 2020, Published online 25 December 2020

\begin{abstract}
High-resolution ocean circulation models have increased our understanding of the movement and distribution of worldwide ocean currents, which were previously unknown and difficult to study. The metabolic expenditure data obtained through open-flow respirometric analysis was put into an energy budget context by comparing it to their available reserved energy in the body upon entering the swimming life phase. We modeled the dispersal range of green turtle hatchling from Chagar Hutang in various monsoon season using the particle-tracking program Ichthyop v3.2 and ocean surface current output from HYCOM (Hybrid Coordinate Ocean Model). The prediction distribution suggests that ocean current variability determines their movements into different dispersal areas. The simulated hatchlings are distributed north into the Gulf of Thailand during the Southwest monsoon, while during the Northeast monsoon, the simulated hatchlings travel south into the Java Sea. By quantifying hatchlings potential energy, they can swim a distance of $116 \mathrm{~km}$ and can last up to 7 days. Green turtle hatchlings from Chagar Hutang reached offshore water of Kelantan State and Terengganu waters near Tenggol Island on Day 7. These findings highlight areas of high priority for conservation, as habitat crucial for an endangered sea turtle species during a critical period of early development.
\end{abstract}

Key words: Ocean model, sea turtle hatchlings, endangered species, conservation, South China Sea

\section{INTRODUCTION}

Sea turtles are known as long-migratory species and experience a phase of oceanic dispersal as hatchlings leaving their natal beach. The period from when hatchlings first crawl down the beach and enter the ocean, until juvenile turtles return to nearshore foraging grounds, has been termed by sea turtle biologists as the 'lost year'. Lost years is one of the remaining gaps in our knowledge of sea turtle hatchlings' life history. Lost years are defined as all kinds of disappearance from human sight about two years during the first period of hatchling's life after they entered the ocean (Witham et al., 1980). Sea turtle hatchlings disperse offshore during their early development until reaching a size range of 35 to $40 \mathrm{~cm}$ (Moon et al., 1997; Hochscheid et al., 2007).

* To whom correspondence should be addressed.
This period of sea turtles early life history is known as the lost years because data on the dispersal range of sea turtle hatchlings, what habitat they occupy, and how they exploit those habitats are extremely sparse, due to the fact that tracking small individual organisms in the open ocean remains extremely difficult (Seney et al., 2010).

Since 1993, more than 1 million sea turtle hatchlings have been released from Chagar Hutang Turtle Sanctuary on Redang Island. However, the distributions of the green turtle hatchlings in the South China Sea and how hatchlings arrive thereafter leaving Chagar Hutang beach remains unknown. Early studies only focused on the distribution of breeding females as they come to nest on the beach, enabling individuals to be deployed easily for satellite attachment (Stoneburner et al., 1982; Timko \& Kolz, 1982; Duron-Dufrenne et al., 1987). However, the recent advancement in 
technologies allows studies to be done on both adult male turtles and sea turtle hatchlings, as the size of the transmitters is reduced (Mansfield et al., 2014). These transmitters help to track the movement of hatchlings and construct a clear map of their 'lost years' journey. There is one study that has been conducted to observe the distribution of sea turtle hatchlings in the South China Sea and discovered that the migration routes of adult turtles are strongly shaped by hatchling drift patterns (Scott et al., 2014). Liew et al. (1995) did the first attempt using satellite telemetry on adult female green sea turtles to study the migration routes. They discovered that the females traveled between $670 \mathrm{~km}$ to over 1700 $\mathrm{km}$ to neighboring countries across international boundaries (Sabah, Philippines, and Indonesia) and do not remain within the island after the breeding season to forage. It has been reported that nesting beaches with high densities of the nest females were found closer to water current that promotes hatchlings dispersal to suitable habitats (Putman et al., 2010; Shillinger et al., 2012; Ascani et al., 2016).

Ocean currents have been hypothesized to strongly influence the distribution of sea turtle hatchlings (Carret et al., 1987; Polovina et al., 2000; Gaspar et al., 2006; Bentivegna et al., 2007; Okuyama et al., 2009). Since Terengganu's coastline faces the South China Sea, it is affected by ocean currents between the seasonal Southwest and Northeast monsoons. The variability of ocean circulation is an essential factor to understand the dispersal route of sea turtle hatchlings. As the strong uni-directional ocean currents that characterize monsoon seasonality in the South China Sea has the potential to transport hatchlings far from their natal beach. This study hypothesized that the dispersal patterns of hatchlings released from Chagar Hutang Beach should be varied due to seasonal changes in ocean current direction between the two monsoon seasons.

Advances in simulation modeling software of ocean currents have giving rise to a new generation of problem-solving tools for sea turtle researchers and conservation management. Previously, researchers have used computer models to predict the movements of sea turtle hatchlings during their early dispersal life stages. However, the common assumption made is that the sea turtle hatchlings are passive drifters, in that they travel along with the directionality of ocean currents towards distant foraging areas (Hays \& Marsh, 1997; Hays et al., 2010; Putman et al., 2010) due to their limitations in swimming abilities. Hatchlings are considered passive drifters since there is limited quantitative data on the locomotors energy of sea turtle hatchlings that can be incorporated into a dispersal model simulation. Recently, researchers have begun to include additional biological information of sea turtles when designing particletracking simulations, for example, swimming behavior can be random, fixed directional, and respond to specific environmental cues, metabolic rates in response to temperature, growth rates related to age, mortality based on temperature and nearshore predation (Putman et al., 2015). This is due to biological information can have a profound influence on their dispersal especially swimming behavior (Putman et al., 2012a, 2012b; Scott et al., 2012). Sea turtle hatchlings are likely to rely on locomotion strategies beyond passive drift and even a minimal amount of swimming activity is likely to have an impact on their survival-ship, obtaining food, and avoiding predators.

The hatchling dispersal phase is an energetically draining phase in the life cycle of sea turtles as it requires hatchlings to exert high energy expenditures of energy, as they crawl and frenzy swim away from their natal beach. The quantification of sea turtle hatchlings' potential energy is a vital step in modeling their interactions with ocean currents and dispersal routes. This study aimed to incorporate sea turtle hatchlings swimming potential (the remaining energy reserves in the body after emerging from their nest). This is to ultimately predict trajectories and their ecological consequences. This study quantified the energetic cost to hatchlings, of nest emergence using an open-flow respirometric system for digging out the process from the nest chamber and swimming performance for 18 hours. With this quantitative data on hatchling's energy expenditure, we calculated the energy reserves of hatchlings to model possible dispersal distances and their first destination once hatchlings finished their energy reserves. The output of the ocean circulation model is usually paired with particle-tracking software that computes the trajectories of particles released within the model (Werner et al., 2007; Lett et al., 2008; Cowen \& Sponaugle et al., 2009). In this study, the characterization of possible dispersal distance with monsoonal influence was developed by particle-tracking software incorporating with ocean current data to answer fundamental questions of sea turtle hatchlings ecology: (i) where are the sea turtle hatchlings from Chagar Hutang beach distributed during monsoon seasons? (ii) how far they can travel with the remaining energy reserves in their residual yolk? (iii) where is their first destination after hatchlings finished their energy reserves? It is hoped that this dispersal model of sea turtle hatchlings which incorporates their swimming potential is useful in providing insights about sea turtle hatchlings; (i) to predict dispersal routes; and (ii) to highlight ocean areas of high conservation priority. 


\section{MATERIALS AND METHODS}

\section{Model simulation}

The green sea turtle is the most extensively distributed sea turtle species in Malaysia particularly in Peninsular Malaysia and East Malaysia. Sabah, Sarawak, and Terengganu have the highest nesting population of green turtles in Malaysia. The study site, Chagar Hutang, is located at Redang Island, Terengganu (Figure 1). Chagar Hutang is a crescentshaped beach $350 \mathrm{~m}$ in length. The beach is divided into 35 sectors, each $10 \mathrm{~m}$ wide along its length. This beach host the largest nesting aggregation of green sea turtles in Peninsular Malaysia.

To stimulate the directionality of sea turtle hatchlings through the ocean, sea surface currents velocity were extracted from a high-resolution 3D ocean circulation model, Global HYCOM (Hybrid Coordinate Ocean Model, https://www.hycom.org/) at $0 \mathrm{~m}$ depth. This data has an equatorial resolution of 1/12 degree. Global HYCOM provides data on surface currents with the influence of wind stress, which are important in predicting the dispersal scenarios of sea turtles (Witherington et al., 2002; Bolten et al., 2003).

Particle tracking software (Ichthyop v.3.2) has been used extensively to model dispersal patterns of sea turtles (Proietti et al., 2014; Putman et al., 2016) and other marine creatures (Pagán et al., 2003; Condie et al., 2011). To estimate the dispersal route of green turtle hatchlings in the South China Sea, this study used particle tracking software
(Ichthyop v.3.2, www.ichthyop.org) to stimulate the paths of virtual particles released from the nesting beach of Chagar Hutang in Redang Island (Figure 1). We defined the release zone between latitudes $0^{\circ} \mathrm{N}$ and $14^{\circ} \mathrm{N}$ and longitudes $99^{\circ} \mathrm{E}$ and $117^{\circ} \mathrm{E}$. One thousand simulated particles were released from $5.9^{\circ} \mathrm{N}$ and $103.008^{\circ} \mathrm{E}$. Trajectories were computed at $1800 \mathrm{~s}$ intervals using the Runge-Kutta fourth-order time-stepping method to stimulate the transport of particles forced by daily averaged surface velocity (Putman et al., 2012b, 2016) in Ichthyop v.3.2 particle tracking software. The particles were released as passive drifters, which did not incorporate the swimming speed of sea turtle hatchlings, as the first aim was to identify whether hatchlings are entrained with ocean currents. To investigate possible variations in the dispersal of sea turtle hatchlings between different seasons, two periods were chosen to coincide with the Southwest monsoon from May to October and the Northeast monsoon from November to March. One thousand simulated particles were tracked for 183 days as passive tracers and were released starting from May 1 until October 31 and then continuing through November 1 until March 31 for 150 days in a separate simulation. The number of released particles were fixed at 1000 at the release site to ensure that datasets are broad enough and not too computerized for model simulations. This was to observe whether season variability may change the direction of sea turtle hatchlings dispersal in the South China Sea.

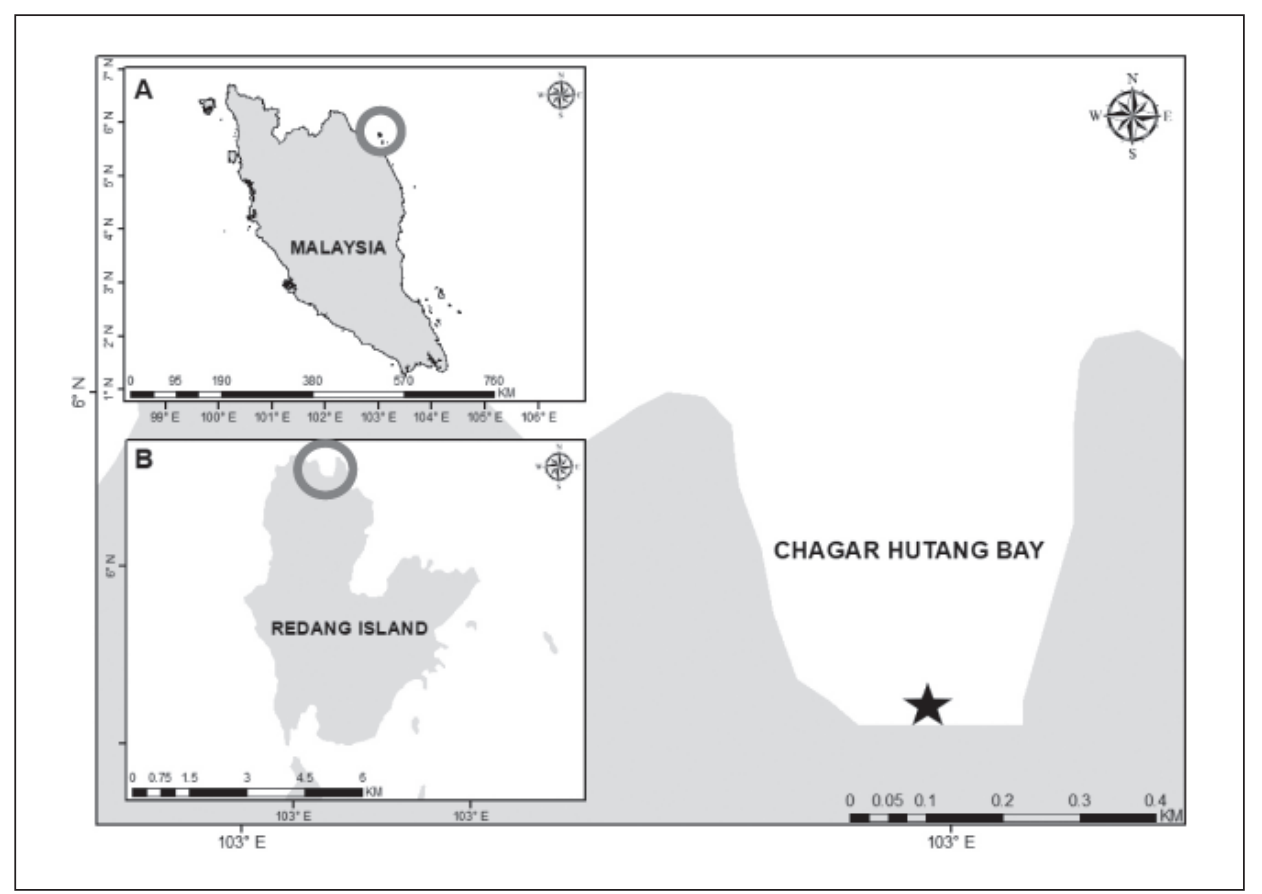

Fig. 1. Map of Redang Island.

Close up view of Chagar Hutang Turtle Sanctuary. Star indicates sea turtle hatchlings release site. 


\section{Biological data on swimming speed}

The swimming speed of the sea turtle hatchlings has been taken into account in this dispersal simulation to obtain a more realistic description of the hatchling dispersal. According to Oñate Casado (2018), the average speed of green sea turtle hatchlings from Chagar Hutang is $0.39 \mathrm{~m} / \mathrm{s}$. Based on the previous results from a which investigated the influence of sand type on the swimming ability and fitness of hatchlings, this study used the mean swimming speed of hatchlings incubated in coarse sand, since they had a stronger swimming ability compared to hatchlings from the fine sand (Nadhirah, unpublished). The swimming speed of sea turtle hatchlings from coarse sand declined to $37 \%$ in the first $8 \mathrm{hr}$ and continued to decline to $22 \%$ until $18 \mathrm{hr}$. The swimming data was inserted in the swimming velocities parameter with age (day); velocities $(\mathrm{m} / \mathrm{s})$ specifications. The simulated turtles were programmed to a speed of $0.390 \mathrm{~m} / \mathrm{s}$ at $0 \mathrm{hr}$ and continuous to reduced. After $24 \mathrm{hr}$ (1 day) we assumed that the speed of the hatchlings remains constant. The drift speed of sea turtle hatchlings on oceanic dispersal was compared among passive drifters' simulated models. Table 1 shows a summary of the Ichthyop experiment in this study.

\section{Survival success of particles}

In the simulation, the behavior of the particles was set into 'beaching' when reaching the coastline to observe the particles' success. Particles were assumed to suffer from mortality under the following criteria: (1) Particles were washed back onshore (beached) and (2) Water depth encountered by turtles. We assumed that hatchlings do not have a chance to survive in water $<10 \mathrm{~m}$ deep away from coral reefs during the first hour at sea.

\section{RESULTS}

The particles were treated as passive drifters (no swimming behavior allocated), to validate the initial pathways of hatchlings' dispersal and identify whether ocean current might influence the dispersal of sea turtle hatchlings in the South China Sea (Figure 2). Then, particles were simulated with a mean swimming speed for $18 \mathrm{hr}$ for comparison to the passive drift model. The results showed that the hatchlings moved similarly with the direction of the ocean currents for both simulations. However, once hatchlings mean swimming speed is included in the simulation, the dispersal areas are broadened and show an increase in the number of particles entering deeper ocean waters. For example, during Northeast monsoon, some of the 'swimming' particles extended $>20 \%$ of their trajectories across the Singapore Straits to Rupat Island (Figure 3), in comparison to particles which only traveled as far as the Bengkalis Island (Figure 2). This indicates that sea turtle hatchlings may disperse farther if they are actively swimming than if they are just drifting along with ocean currents. A major divergence was observed in a direction to the ocean currents and therefore hatchling dispersal between the Southwest monsoon and Northeast monsoon. The only difference observed between the no assigned and assigned mean swimming speed were the velocities of the particles decreased as the mean swimming speed of the hatchlings was included. These results suggested that the hatchlings were dispersing uni-directionally and this might be attributable to ocean currents.

\section{Monsoonal influence}

The simulated dispersal of 1000 particles showed seasonal variation in ocean currents offer

Table 1. Summary of Ichthyop experiment in this study

\begin{tabular}{ll}
\hline & Variables \\
\hline Release time & Southwest monsoon: 01 May 2017 - 31 October 2017 \\
& Northeast monsoon: 01 November 2017 - 31 March 2018 \\
Number of sea turtle hatchlings release & 1000 \\
Release zone (Chagar Hutang) & Longitude (East degree) $-103 \mathrm{E}$ \\
& Latitude (North degree) $-5.90 \mathrm{~N}$ \\
Depth & $0.0 \mathrm{~m}$ (surface) \\
Radius & 8000.0 \\
Thickness of stain (meter) & 1.0 \\
Coastline behavior & Beaching \\
Swimming speed & $0.0-0.390 \mathrm{~m} / \mathrm{s}$ \\
& $0.3-0.25 \mathrm{~m} / \mathrm{s}$ \\
& $0.6-0.22 \mathrm{~m} / \mathrm{s}$ \\
& $1.0-0.20 \mathrm{~m} / \mathrm{s}$ \\
& $2.0-0.20 \mathrm{~m} / \mathrm{s}$ \\
\hline
\end{tabular}




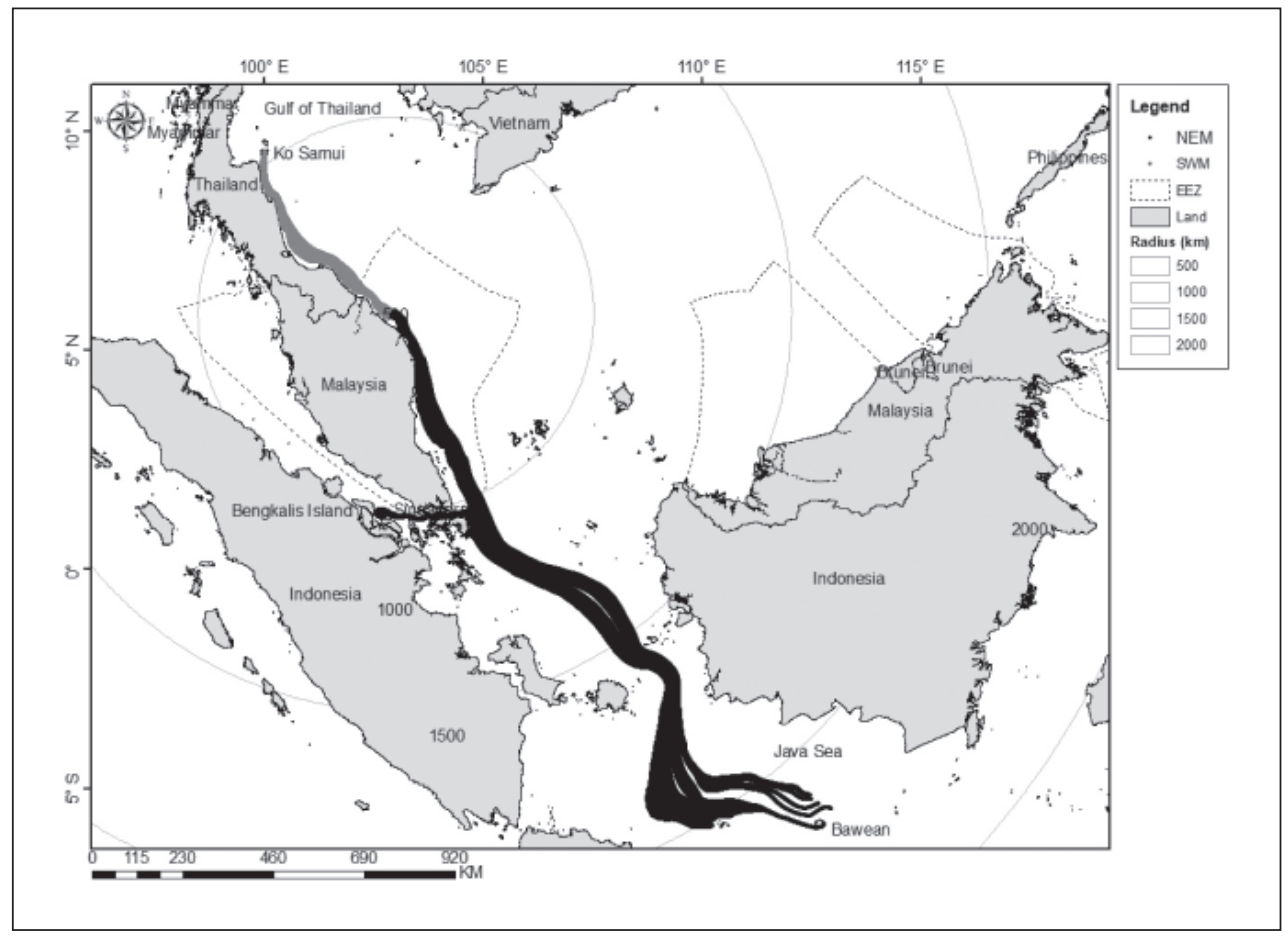

Fig. 2. Possible dispersal routes of sea turtle hatchlings from Chagar Hutang.

The trajectories of virtual drifting particles (no swimming speed assigned) were released from Chagar Hutang, Redang Island during two different monsoon seasons. Red tracks indicate Southwest monsoon, SWM dispersal (183 days) and black tracks indicate Northeast monsoon, NEM (150 days). Grey circular represents the radius $(\mathrm{km})$ of particles traveled.

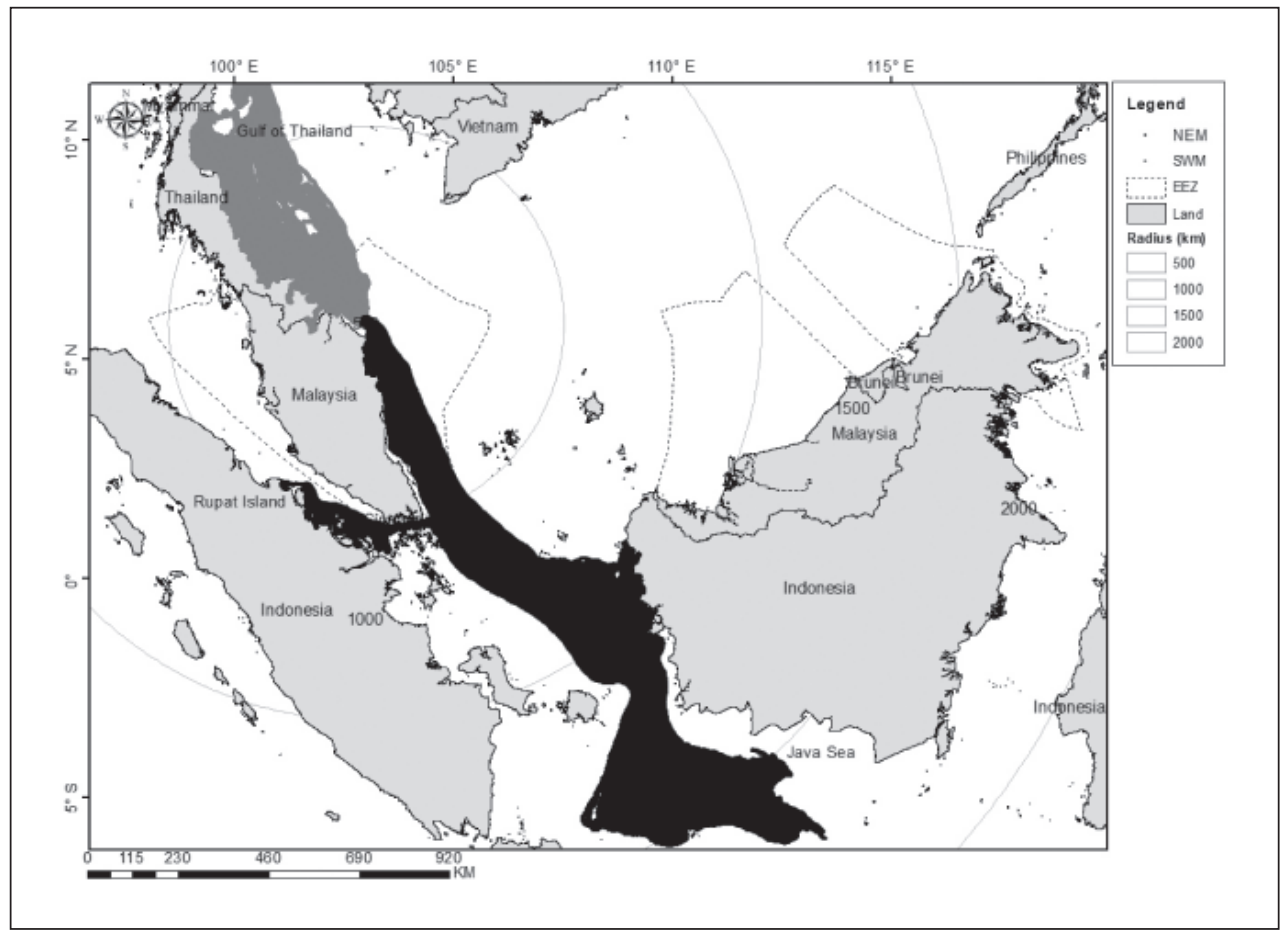

Fig. 3. Possible dispersal routes of sea turtle hatchlings from Chagar Hutang.

The trajectories of virtual swimming particles (swimming speed assigned) were released from Chagar Hutang, Redang Island during two different monsoon seasons. Red tracks indicate Southwest monsoon, SWM dispersal (183 days) and black tracks indicate Northeast monsoon, NEM, (150 days). Grey circular represents the radius $(\mathrm{km})$ of particles travelled. The area of dispersal is broadened. 
sea turtle hatchling multiple dispersal routes way from their natal beach. The simulation showed that the dispersal routes of the particles covered nearly the entire South China Sea. Along the South China Sea, particle trajectories varied with the changing monsoon season, with particles moving northward during the Southwest monsoon (dry season) and moving southward during the Northeast monsoon (wet season) when released from Chagar Hutang (Table 3). Table 2 shows the data on the number of nest and hatchlings production in 2019 (SEATRU, unpublished data).

Particles released during the Southwest monsoon were distributed northwards and traveled as far as the Gulf of Thailand (Figure 3). The particles were tracked for 183 days with distance traveled ranging between $700 \mathrm{~km}$ to $770 \mathrm{~km}$. While moving northward, some of the particles traveled into shallow waters close to the shores of Ko Samui, Ko Phangan, and Ko Tao. All the particles dispersed into waters within the Exclusive Economic Zone of Thailand, outside of Malaysian jurisdictional.

Particles released during the Northeast monsoon were distributed as far as the Java Sea. Particles were tracked for 150 days with distance traveled ranging between $975 \mathrm{~km}$ to $1,900 \mathrm{~km}$ within a radius of nearly $2000 \mathrm{~km}$. During the Northeast monsoon, particle moved southward along the coast of Johor State in between Tioman Island, after which the particles continue to disperse following two trajectories; i) moving through the Singapore Strait towards Rupat Island, and ii) moving southward into the Java Sea and passed Bawean Island and into the open sea. A small proportion of particles dispersed towards West Kalimantan in the simulation. Most particles moved southwards along the coast until Singapore before being carried east into deeper water, while only a few particles moved westwards into the Singapore Strait. During the Northwest monsoon, all the simulated particles dispersed into the Exclusive Economic Zone waters of Indonesia outside of Malaysian jurisdictional.

Both trajectories are correlated with the direction of the ocean currents in the South China Sea (Figure 4). There was obvious variation in ocean current as the particles released during different monsoon seasons comparatively headed to different directions. It is considered that the trajectories of the hatchling dispersals from Chagar Hutang, can be related to the dispersal route of particles in these simulations, due to the fact that ocean currents of the South China Sea are a major factor that influences the dispersal route of sea turtle hatchlings.

\section{Survival success}

The unsuccessful survival of particles was assumed when the particles released returned to land (beaching), or into shallow water. Beaching behavior was observed more during the Southwest monsoon where most of the particles beached in Thailand. Meanwhile, most of the particles released during the Northeast monsoon were survived as they end up in $>50$-meter-deep water (Figure 5). Chagar Hutang is in the South China Sea where this region's ocean current is influenced by seasonal wind directions, particularly during the Southwest monsoon and Northeast monsoon seasons. Results from particle dispersal simulations show that most of all particles released during the dry season were beached, due to consistently strong onshore winds during the Southwest monsoon. Although many particles in the simulation resulting in being

Table 2. Data on the number of nest and hatchlings produced in Chagar Hutang in 2019 to provide range number in Table 3

\begin{tabular}{ccc}
\hline Month & Nest & Hatchlings \\
\hline J & 7 & 310 \\
F & 14 & 775 \\
M & 69 & 3356 \\
A & 177 & 7839 \\
M & 312 & 14075 \\
J & 379 & 15270 \\
J & 300 & 6023 \\
A & 168 & 5565 \\
S & 75 & 1598 \\
O & 20 & 840 \\
N & N/A & N/A \\
D & N/A & N/A \\
\hline
\end{tabular}

Table 3. Monsoon seasons and wind direction in Terengganu Water with nesting season and hatchlings production in Chagar Hutang Turtle Sanctuary

\begin{tabular}{ccccc}
\hline Month & $\begin{array}{c}\text { Monsoon } \\
\text { season }\end{array}$ & $\begin{array}{c}\text { Wind } \\
\text { direction }\end{array}$ & $\begin{array}{c}\text { Nesting } \\
\text { season }\end{array}$ & $\begin{array}{r}\text { Hatchling } \\
\text { production }\end{array}$ \\
\hline J & NE & $\downarrow$ & Low & Low \\
F & NE & $\downarrow$ & Low & Low \\
M & NE & $\downarrow$ & Low & High \\
A & IM & MD & High & High \\
M & SW & $\uparrow$ & Peak & Peak \\
J & SW & $\uparrow$ & Peak & Peak \\
J & SW & $\uparrow$ & Peak & High \\
A & SW & $\uparrow$ & High & High \\
S & SW & $\uparrow$ & Low & High \\
O & SW & $\uparrow$ & Low & Low \\
N & NE & $\downarrow$ & N/A & N/A \\
D & NE & $\downarrow$ & N/A & N/A \\
\hline
\end{tabular}

NE (Northeast Monsoon), SW (Southwest Monsoon), IM (Intermonsoon), Arrow down (Southward), Arrow up (Northward), and MD (Multi-direction). The range number of nests: Low $(<100)$, Peak $(>300)$, High $(>100)$. The range number of hatchlings produced: Low $(<1000)$, Peak $(>10,000)$, High $(>1000)$. 


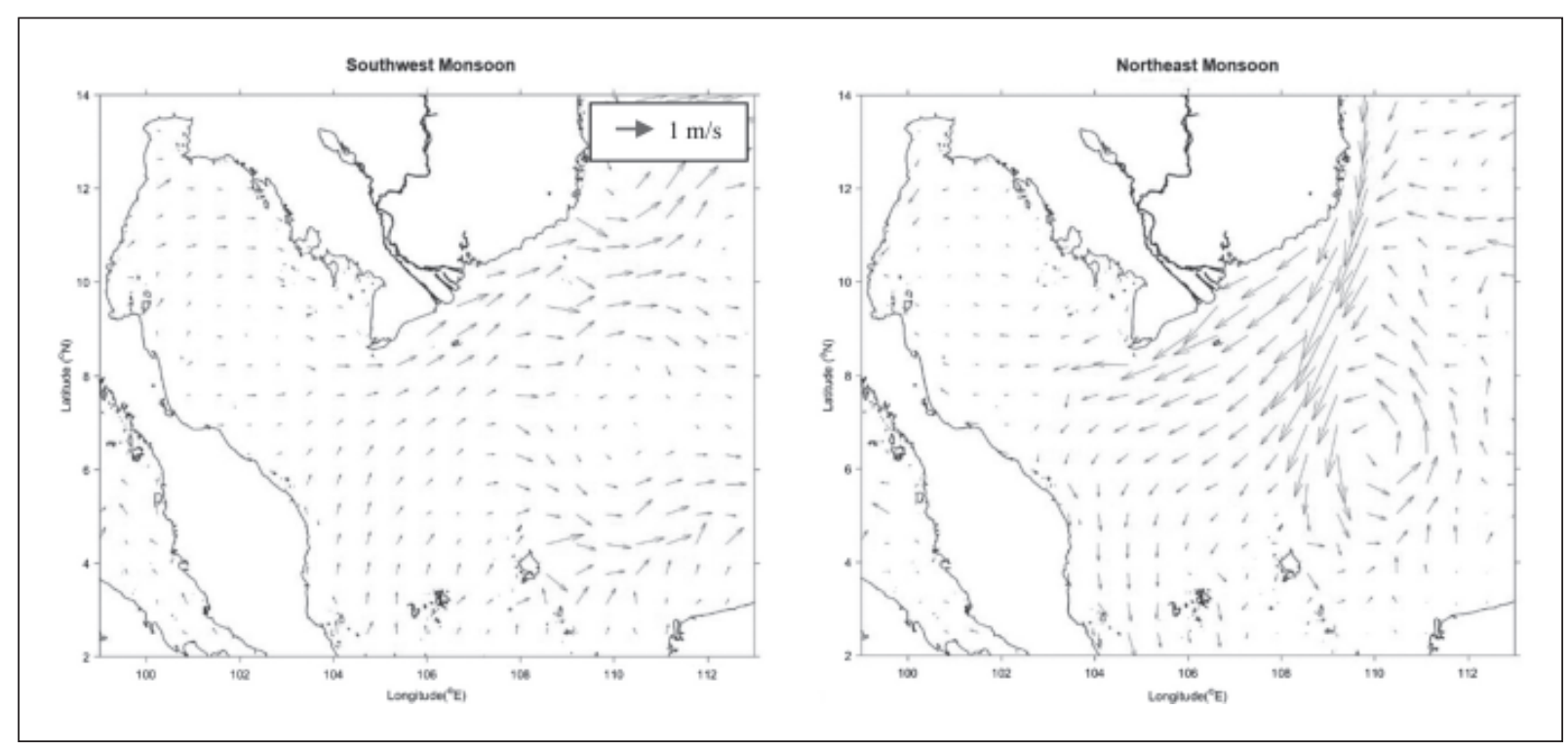

Fig. 4. Prevailing ocean currents around the South China Sea.

Mean surface ocean currents during Southwest monsoon and Northeast monsoon.

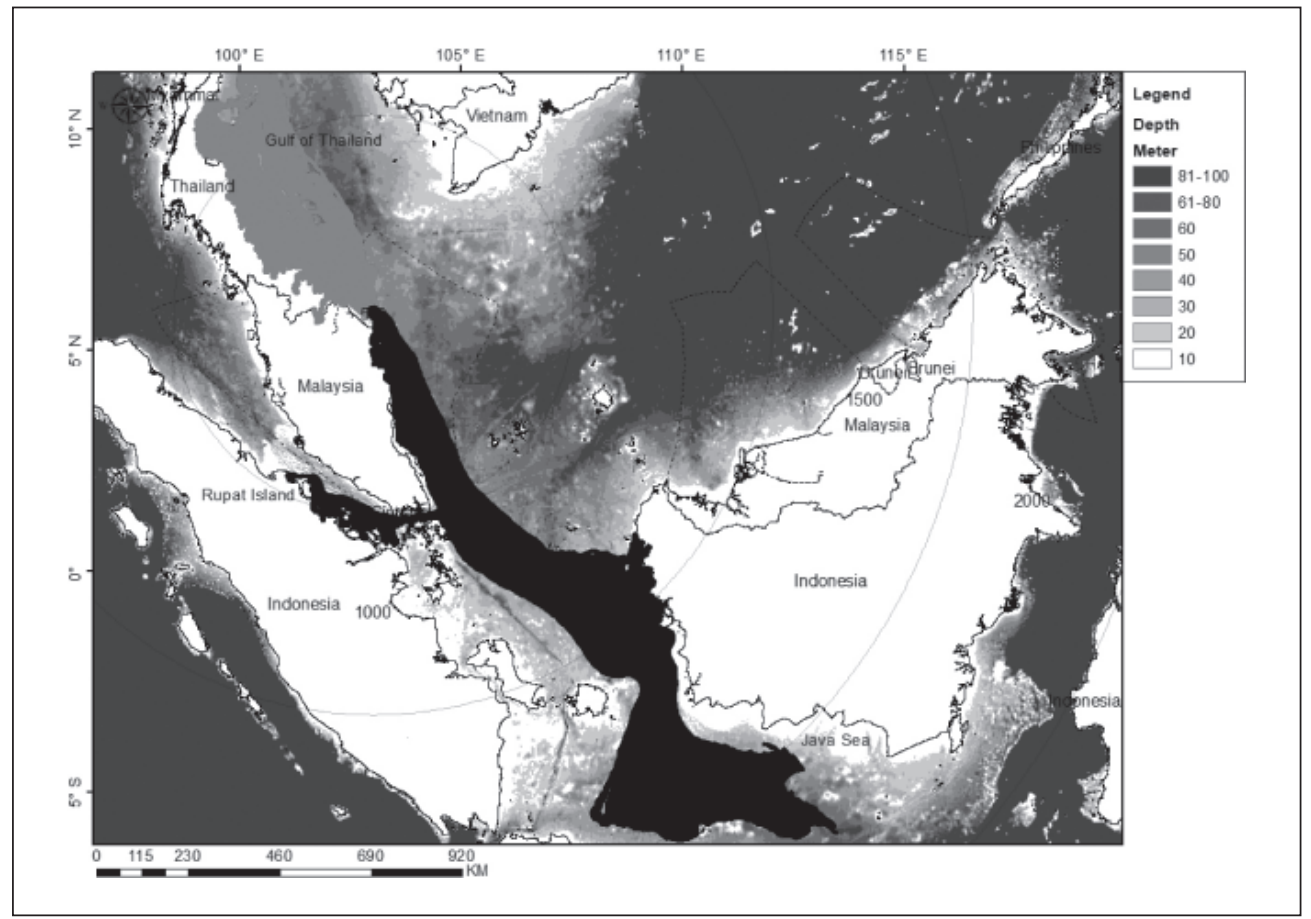

Fig. 5. Water depth of the South China Sea.

Grey shading indicates bathymetry with scale as shown in the figure. Red tracks indicate Southwest monsoon, SWM dispersal (183 days) and black tracks indicate Northeast monsoon, NEM (150 days).

beached, its theorized hatchlings swimming ability would allow them to avoid this fate in the real life. The majority of particles released during the wet season survived from becoming beached as they were transported away from coastal areas towards the direction of deeper ocean waters. Based on this result, green turtle hatchlings released during the Northeast monsoon season will have the highest success rate of dispersing into oceanic habitats and further developing into juvenile turtles.

\section{First destination reach}

The main goal of this study was to accurately model sea turtle hatchling dispersal in the South China Sea by incorporating the residual energy reserves of hatchlings after post-hatching activities 
into oceanic particle dispersal simulations. There is no direct parameter available to insert the energy value into Ichthyop v.3.2 particle simulation software, to project the exact dispersal route of the hatchlings from Chagar Hutang depending on their energy reserves. The only way to identify which destinations are reached by sea turtle hatchlings after consuming their entire energy reserves is to manually calculate the distance hatchling will be able to travel from the results of previous studies.

Assuming that hatchlings are consuming $30 \mathrm{~mL}$ $\mathrm{O}_{2}$ per hour immediately when they enter the water (Booth et al., 2009), and use an oxycalorific conversion factor of $19.7 \mathrm{~J}$ per $\mathrm{ml} \mathrm{O} 2$ (SchmidtNielsen et al., 1997), then the rate of energy consumption is $0.164 \mathrm{~J} / \mathrm{s}$. The average swimming speed of green sea turtle hatchlings from Chagar Hutang, $0.39 \mathrm{~m} / \mathrm{s}$ (Oñate Casado et al., 2018), was assumed as the speed at which the hatchlings are capable of swimming immediately after they enter the water. By combining these parameters, this study calculated how much energy it takes for a green turtle hatchling to swim in one meter, $0.42 \mathrm{~J}$ of energy when hatchlings immediately enter the water and were swimming at their maximum speed. Noted that this value probably decreases a bit when hatchlings are swimming at a slower speed, because there will be less drag to overcome at slower swimming speeds. Green turtle hatchlings contain on average, $49 \mathrm{~kJ}$ in their residual yolk at hatching (Booth et al., 2009), in theory, hatchlings can swim a distance (if they were able to swim at full speed continuously) of $116 \mathrm{~km}$ without having to feed. Therefore, this study assumed that $116 \mathrm{~km}$ is the maximum furthest distance that green turtle hatchlings can swim to using the energy reserves in their residual yolk. Sea turtle hatchlings need to begin swimming immediately upon entering the ocean to avoid predators and increase their chances of survival. After embryonic development, the residual yolk of green sea turtle hatchling contains on average $\sim 49 \mathrm{~kJ}$ of energy (Booth et al., 2009), which the hatchlings use for digging, crawling, and swimming activities. According to Rusli (2016), green turtle hatchlings use 5 to $25 \mathrm{~kJ}$ of energy during nest escape. In this study, we assumed that all the hatchlings used $5 \mathrm{~kJ}$ of energy during nest escape and only $0.54 \mathrm{~kJ}$ when crawling down the beach towards the ocean (Williams et al., 2012). Energy values for both activities were deducted from $49 \mathrm{~kJ}$, leaving only $43.46 \mathrm{~kJ}$ remaining in a hatchling's energy reserves. According to Booth (2009), only about $6 \mathrm{~kJ}$ of energy is expended by hatchlings during the first $24 \mathrm{hr}$ of swimming activity. Incorporating the data above, we calculated that a hatchling could survive for 7 days of continuous swimming using the residual energy reserves in their body (Figures 6 and 7). Considering that turtle hatchlings continue to swim continuously after their first day at sea, this survival period may extend to two weeks (Wyneken \& Salmon, 1992). Using 7 days as the average length of time hatchlings can survive without feeding, our study examined the location of particles in the dispersal simulations to determine the location of hatchling when they would need to start feeding. It is theorized that hatchlings released from Chagar Hutang beach during the Southwest monsoon season would reach waters offshore Kelantan state, while during Northeast monsoon season they would remain in Terengganu waters near Tenggol Island.

\section{DISCUSSION}

Plotting the migration routes of sea turtle using particle tracking models with ocean circulation has been widely studied for hatchlings, juveniles, and adult turtles (Godley et al., 2010; Putman et al., 2010; Okuyama et al., 2011; Putman et al., 2012a; Putman \& He, 2013; Putman \& Mansfield, 2015; Briscoe et al., 2016; Christiansen et al., 2016; Endres et al., 2016; Putman et al., 2016; Mansfield et al., 2017; Robson et al., 2017). The results suggest that the swimming behavior of sea turtle hatchlings influenced their migratory trajectories although the swimming speed is much slower than ocean currents. This is supported by Scott et al. (2012) and Putman et al. (2012a, 2012b) that state hatchling swimming behavior can have a profound influence on their dispersal. However, their migratory trajectories are still entrained within the direction of ocean currents. Since hatchlings have a limited amount of energy reserves left in their body for swimming after post-hatching activities, they used limited directional swimming with the help of ocean currents to help stay on course during dispersal and carry them to favorable nursery grounds. Results from this experiment show that small amounts of directional swimming provided an advantage to some particles, where they were more likely to be transported to deeper waters than those that were drifting passively (Figures 2 and 3). Virtual particles in the simulation represented hatchling turtles, thus they can behave differently from juveniles and adults. Juvenile and adult turtles are expected to move against water currents and travel farther they are capable of finding their food in compared to sea turtle hatchlings. As the hatchlings grow into juveniles, their swimming abilities improve, and they show directional swimming by adjusting their direction to ocean currents to favorable areas (Lohmann et al., 2001).

These results represent the first particle-tracking of sea turtle hatchlings in the South China Sea water during monsoon season. The simulation 


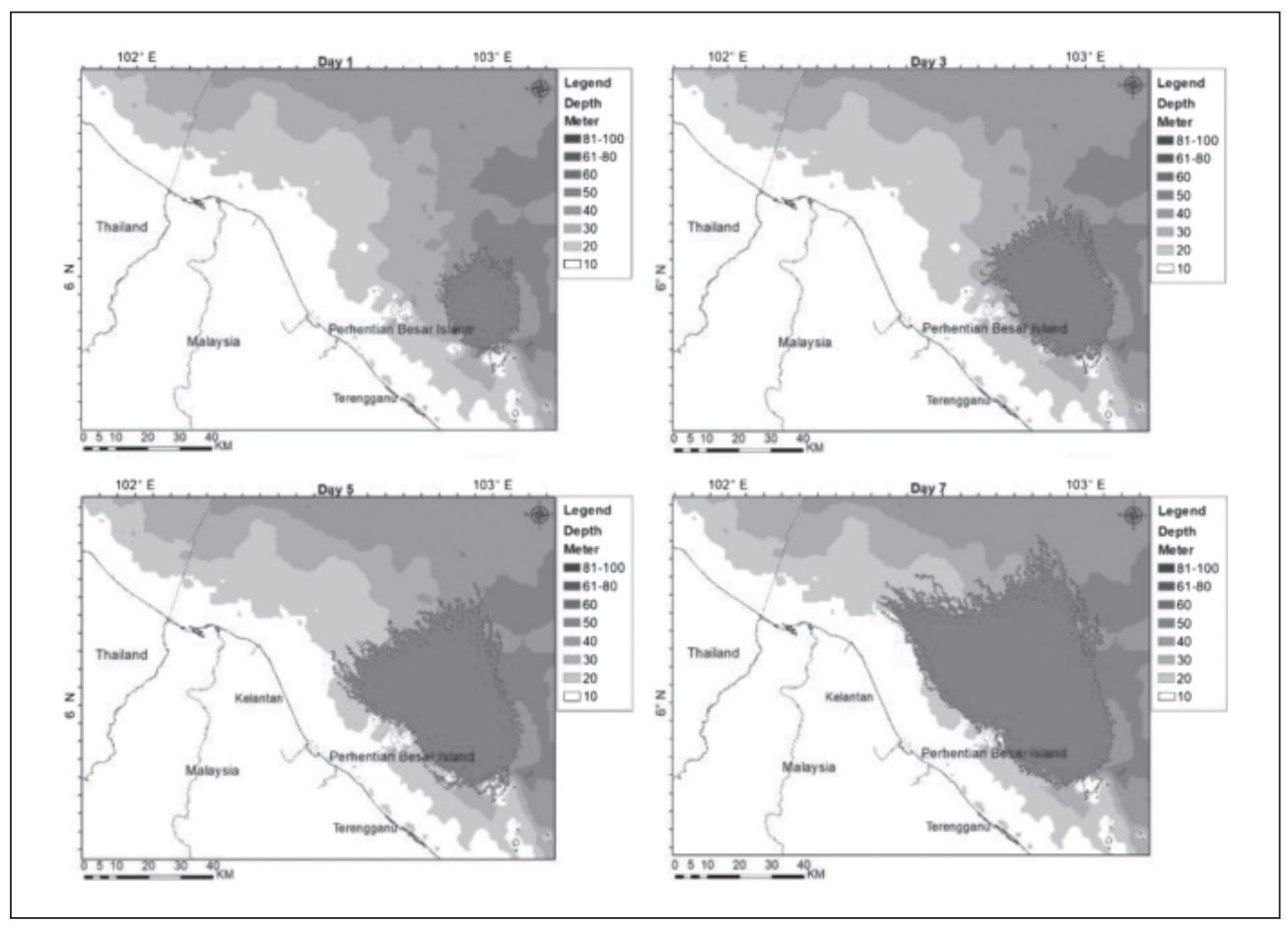

Fig. 6. The approximate distance traveled by hatchlings is $116 \mathrm{~km}$ over 7 days without feeding. Red tracks indicate Southwest monsoon, SWM dispersal. Day 7 is the destination reach of green turtle hatchlings from Chagar Hutang Beach after energy is fully utilized in the body.

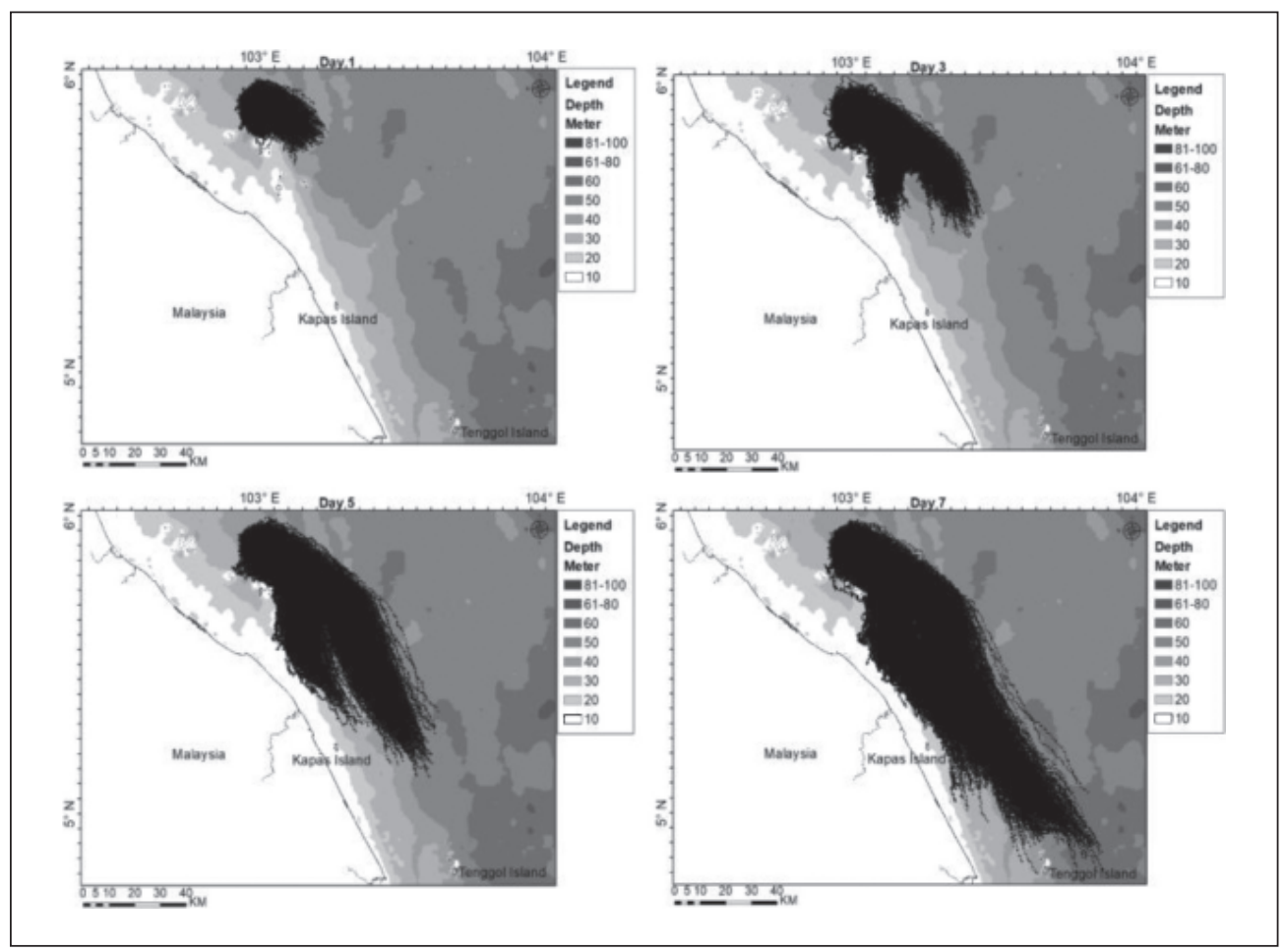

Fig. 7. The approximate distance traveled by hatchlings is $116 \mathrm{~km}$ over 7 days without feeding. Black tracks indicate Northeast monsoon. NEM dispersal. Day 7 is the destination reach of green turtle hatchlings from Chagar Hutang Beach after energy is fully utilized in the body. 
demonstrated that the distribution of particles was markedly between two monsoon seasons where ocean currents change directionality. For example, in just more than 100 days after leaving the Chagar Hutang beach, simulated particles dispersed over a large area in the Gulf of Thailand water and into Indonesia waters in the South China Sea (Figure 3). Changes in particle dispersal trajectories occurred in conjunction with seasonal variation in ocean current direction in the South China Sea (Figure 4). Ocean current circulation patterns in the South China Sea are influenced by strong seasonal winds during the northeast and southwest monsoon (Camerlengo \& Demmler, 1997; Fang et al., 2002; Akhir et al., 2014). During the northeast monsoon from November to March, Chagar Hutang receives strong northeasterly wind approximately $0.3 \mathrm{Nm}^{2}$ wind stress resulting in greater southward flow and transport. While, during the southwest monsoon from May to October, this region prevails by the southwesterly wind with almost $0.1 \mathrm{Nm}^{2}$ wind stress resulting in northward flow and transport (Akhir et al., 2012). Particles tended to move northward to the Gulf of Thailand and southward into Indonesian waters in response to changes in ocean surface currents. This study indicated that even in the presence of swimming behavior, hatchlings dispersal remains largely shaped by oceanic currents, as commonly observed in previous hatchling dispersal studies (Carr et al., 1987; Hamann et al., 2010; Okuyama et al., 2011; Putman et al., 2012b). It is theorized that hatchling moves along with their prey (planktons) and flotsam seaweeds which drift passively with ocean currents (Witherington et al., 2012; Mansfield et al., 2014). This study illustrated that hatchlings entering the ocean from Chagar Hutang can disperse into different oceanic areas within few months of seasonal variability.

The current study showed that hatchlings from Chagar Hutang are driven northward into the Gulf of Thailand by ocean currents during Southwest monsoon, while during Northeast monsoon hatchlings are driven southward to the Java Sea and end up in the open ocean by Bawean Island (Figure 3). To support these findings, data from the published study on a Lagrangian analysis (Scott et al., 2014) that passed the South China Sea regions were compared. This publication provided data from 42 sites around the world to compare the migration routes of more than 400 satellites adults from multiple species of the sea turtle with 45,000 particle tracking trajectories and 1794 trajectories from 1398 surface drifter buoys. Scott et al. (2014) study proved that particle tracking trajectories and surface drifter buoys trajectories have the same large-scale ocean circulation patterns. Similarly, the results of particle simulations from this study support the hypothesis that the hatchlings disperse broadly to the Gulf of Thailand and the Indonesia Sea in line with a strong bifurcation in ocean circulation at the respective release site. Year-long trajectories show that the simulated particles traveling north into the Gulf of Thailand were transported as far and the coast of Vietnam. Whereas, the majority of the particles that dispersed southerly were transported into deeper waters of the Java Sea. Also, the lagrangian drifter data that passed near the Pulau Redang nesting beaches show that 10 buoys reached the east coast of Peninsular Malaysia, 4 buoys reached the junction of the South China Sea and the Java Sea, and 1 buoy reached the Singapore Strait (Nishizawa et al., 2016). Consequently, in the current study, no particles were observed to reached Riau Archipelago as in the previous study (Scott et al., 2014) where the particles transported broadly easterly-southerly. Hypothetically, if the simulated particles are simulated continuous for one year, most simulated hatchlings emerging from Chagar Hutang Beach may initiate their oceanic journey moving southeastward under the influence of the South China Sea current water correlated to the previous study. Thus, these seasonal drift patterns have been shown to play an important role in transporting green turtle hatchlings from nesting beaches for oceanic dispersal.

Monzón-Argüello et al. (2010) and Scott et al. (2014) provide strong evidence that the passive drift routes experienced by sea turtle hatchlings may shape their adult migration routes. This is supported by genetic studies of nesting mothers with a combination of hatchlings drift pattern by lagrangian drifter buoy data in Malaysia suggests that there have been migrations from various rookeries to foraging grounds in Southeast Asia (Nishizawa et al., 2016). Turtles modeled as passive drifters from Chagar Hutang had a higher probability of reaching the distant foraging grounds of Pulau Tiga, Bangka Island, Balabac Strait, Natuna Island, Tambelan Island, and Bungsuk Island as mentioned in Liew et al. (1995) and Luschi et al. (1996) to continue their growth development. However, Natuna Island was assumed to be the resting site of nesting mothers from Chagar Hutang for 1.5 months after the long post-reproductive non-stop journey to the foraging ground (Papi et al., 1995). This implies that the location of a nesting beach from which green turtle hatchlings disperse plays a central role in determining subsequent dispersal scenarios of juvenile and adult turtles (Putman et al., 2012a). A previous satellite by Luschi et al. (1996) showed that one of the tracked female green turtles from Chagar Hutang reached the Brunei coast in Borneo and this area might be reached by green turtle hatchlings from 
Chagar Hutang. This suggested that there is a link between Peninsular Malaysia nesting beaches and the Brunei Bay foraging ground, with this area being mostly utilized by adult green turtles. However, a recent study indicated, through the size distribution of sampled green turtles at the Brunei bay foraging ground, that it was utilized by large green turtle juveniles or adults $(\mathrm{CCL} \geq 65 \mathrm{~cm})$ (Jospeh et al., 2016). The Brunei Bay foraging ground was used as a temporary site by green turtles shifting from other foraging grounds after the oceanic development phase to the more productive foraging round of Brunei Bay (Pilcher et al., 2010). One of the reasons why Brunei Bay is not utilized by small juvenile turtles could be the ocean's surface currents. Nishizawa et al. (2016) suggested that it is difficult for hatchlings born in nesting beaches in Peninsular Malaysia and the Sulu Sea to reach Brunei Bay by passive drifting due to the Southward current flow from peninsular Malaysia and counterclockwise current flow in the South China Sea. Therefore, a long-term study on hatchling dispersal patterns from Chagar Hutang is needed to prove the findings.

In the particle dispersal simulation, the Southeast monsoon ocean currents were weaker compared to the Northeast monsoon. However, most of the particles released during the Southwest monsoon resulted in beaching episodes, while particles released during the Northeast monsoon were observed to have a higher success of reaching deeper ocean waters (Figure 5), this could due to the changes in the strength of ocean circulation in the South China Sea (Robson et al., 2017). It is suggested that those hatchlings that manage to swim offshore (pass $>10 \mathrm{~m}$ deep water) have a greater chance of survival within the first hr of dispersal. This is because water depth is correlated with predation risk whereby the density of predators is relatively higher in coastal areas $(<10 \mathrm{~m}$ depth $)$ (Carr et al., 1987; Collard \& Orgen, 1990; Wyneken \& Salmon et al., 1992; Whelan \& Wyneken, 2007; Wyneken et al., 2008). Oñate Casado et al. (2018) indicated that $87.5 \%$ of the green turtle hatchlings from Chagar Hutang were predated in water shallower than $8 \mathrm{~m}$ while $12.5 \%$ predation events occurred at distances greater than $150 \mathrm{~m}$ from shore. This is because Chagar Hutang Bay, the coral reef communities colonize in the shallow part of the bay. Therefore, the longer the time hatchlings spend in shallow nearshore areas, the greater the risk of mortality (Glenn et al., 1998; Harewood \& Horrocks, 2008). Future studies on hatchling dispersal should include the rate of predation and mortality in the shallower part of the bay and the open ocean within particle simulation to better understand the migratory range of sea turtle hatchlings.
This is the first study that attempts to identify the possible location of green sea turtle hatchlings when their residual energy reserves are finished during their early dispersal. This study calculated based on the measurements of energy expenditure that green turtle hatchlings can travel a distance of $116 \mathrm{~km}$ for 7 days relying on the energy reserves left in their residual yolk. The results suggest that the offshore water of Kelantan state and Terengganu waters near Tenggol Island might be the possible foraging hotspots for oceanic hatchlings due to the presence of upwelling and vertical mixing along with the areas (Figures 6 and 7) (Ooi et al., 2013; Akhir et al., 2015; Kok et al., 2015). Upwellings occur when the deeper nutrient-rich cold water currents are brought to the surface by geological underwater formations (National Oceanic and Atmospheric Administration, 2018). Results from satellite-derived SST and nutrient concentration analysis confirmed the presence of upwelling along the Peninsular Malaysia's east coast during the Southwest monsoon through an Ekman upwelling theory (Akhir et al., 2015), according to which the higher nutrient concentration recorded is probably attributed to the Kelantan river and/or Thailand (Aziz et al., 2019). Meanwhile, the increase of nutrient concentrations was observed in off-coast areas during the Northeast monsoon, mainly brought by efficient vertical mixing due to turbulent high waves generated by strong winds passing over the ocean's surface, which mixes the surface water with the bottom water (Ooi et al., 2013). Nutrient-rich waters support the growth of plankton and algae, which provides abundant food resources and shelter for sea turtle hatchlings. Hence, these areas need to be protected and conserved, as they serve as nursery grounds to the hatchlings from Chagar Hutang beach, to prevent further population declines and ensure the species' survival during early development stages. For future understanding, comparing the feeding areas with satellite images to provide comprehensive overviews on patterns of ocean productivity to possibly correlate with chlorophyll content in those particular areas should be considered.

Although the present simulation model was based in part on limited knowledge of hatchling swimming behavior and energy reserves, the present study contributes greatly to the improved understanding of sea turtle hatchlings dispersal in the South China Sea. To date, most attempts to model the active dispersal of sea turtles, have not put into consideration the reserved energy value of the hatchlings. Therefore, future studies on hatchling dispersal should incorporate an energy budget value into the simulation to improve the better understanding of the dispersal of sea turtle hatchlings worldwide. 


\section{Management and conservation of sea turtles in Malaysia}

Particle tracking by ocean model software was used in this study to plot the migration paths of green turtle hatchlings after leaving Chagar Hutang beach. The high-resolution ocean circulation models appear to be a powerful tool for predicting the dispersal and distribution of sea turtle hatchlings across large ocean basins. This approach can be applied in numerous studies to investigate the distribution range and the duration drift between habitats. This study showed that green turtle hatchlings from Chagar Hutang, Redang Island distributed across the South China Sea moving to the Gulf of Thailand during Southwest monsoon and moving to the Java Sea during the Northeast monsoon. Additionally, this tool help to predict their possible areas of foraging ground at offshore water of Kelantan State and Terengganu waters near Tenggol Island once hatchlings finished their energy reserves. The results were potentially useful in understanding the fate of new recruitment of sea turtles during their oceanic life phase and could be served as a guideline for authorities to map and establish any new significant marine sanctuaries in the South China Sea region. These findings can be used to recommend the range of offshore protection required for proper management across the South China Sea. Long term study using particle tracking software combined with a large scale satellite telemetry on hatchlings required to identify and highlights further foraging sites, and countries in the region that Peninsular Malaysia authorities would need to collaborate with to effectively manage sea turtle population. Therefore, this study has contributed to the knowledge of spatial population structure and ecology in the South China Sea; as well as help to solve the long-standing question about life history 'lost years' of sea turtle hatchlings. In the future, this tool perhaps could be most useful for conservation planning and management as it can provide a better understanding of hatchlings distribution and movement effectively.

\section{CONCLUSION}

The particle simulation model showing that the dispersal patterns of 1000 simulated hatchlings, offers multiple pathways when released from Chagar Hutang beach at a different time of the various season. The virtual particles travel north into the Gulf of Thailand during the Southwest monsoon season, while during the Northeast monsoon season the particles travel south into the Java Sea. The distribution of the hatchlings from their natal beaches is strongly influenced by ocean currents due to the geographical location of Terengganu waters which influence by ocean current direction. The key findings of this study were after digging and crawling activities, the hatchlings can travel a maximum distance of $116 \mathrm{~km}$ for 7 days, with the reserved energy in the body without being feed. It is suggested that offshore water of Kelantan state and Terengganu waters near Tenggol Island might be the important feeding and nursery habitats for green turtle hatchlings from Chagar Hutang and these areas need to be highlighted as areas of high conservation priority. This study was the first attempt to predict the distance hatchlings are capable of traveling based on the energy reserves after post-hatching activities. Furthermore, future researchers encourage to model the dispersal paths of hatchlings with consideration for their energy reserves using particle-tracking models. Such information is sorely needed to enhance our understanding of sea turtle hatchling distributions around the world and will help make the 'lost years' sea turtle development a little less mysterious.

\section{ACKNOWLEDGEMENTS}

Special thanks to the Sea Turtle Research Unit (SEATRU) and Faculty of Science and Marine Environment, Universiti Malaysia Terengganu for supporting the field research and facilities. We are very grateful to The Taaras Beach and Spa Resort for providing lab and space to conduct the experiment and their generous cooperation. We also thank Nicholai Tolchinsky for the English language review and Yuzwan Mohamad for GIS mapping. This work was supported and funded by the Fundamental Grant Research Scheme (FRGS Vot 59488), The Government of Malaysia.

\section{REFERENCES}

Akhir, M.F. 2012. Surface circulation and temperature distribution of southern South China Sea from global ocean model (OCCAM). Sains Malaysiana, 41(6): 701-714.

Akhir, M.F. 2014. Review of current circulation studies in the southern south china sea. Journal of Sustainability Science and Management, 9(2): 21-30.

Akhir, M.F., Daryabor, F., Husain, M.L., Tangang, F. \& Qiao, F. 2015. Evidence of upwelling along Peninsular Malaysia during southwest monsoon. Open Journal of Marine Science, 5(3): 273.

Ascani, F., Van Houtan, K.S., Di Lorenzo, E., Polovina, J.J. \& Jones, T.T. 2016. Juvenile recruitment in loggerhead sea turtles linked to decadal changes in ocean circulation. Global Change Biology, 22: 3529-3538. 
Aziz, A.A., Suratman, S., Kok, P.H. \& Akhir, M.F. 2019. Distribution of nutrients concentration in the upwelling area off the east coast of peninsular malaysia during the southwest monsoon. Malaysian Journal of Analytical Sciences, 23(6): 1030-1043.

Bentivegna, F., Valentino, F., Falco, P., Zambianchi, E. \& Hochscheid, S. 2007. The relationship between loggerhead turtle (Caretta caretta) movement patterns and Mediterranean currents. Marine Biology, 151: 1605-1614.

Bolten, A.B. 2003. Variation in sea turtle life history patterns: neritic vs. oceanic developmental stages. The biology of sea turtles, 2: 243-257.

Booth, D.T. 2009. Swimming for your life: locomotor effort and oxygen consumption during the green turtle (Chelonia mydas) hatchling frenzy. Journal of Experimental Biology, 212(1): 50-55.

Briscoe, D.K., Parker, D.M., Balazs, G.H., Kurita, M., Saito, T., Okamoto, H., Rice, M., Polovina, J.J. \& Crowder, L.B. 2016. Active dispersal in loggerhead sea turtles (Caretta caretta) during the 'lost years'. Proceedings of the Royal Society B: Biological Sciences. The Royal Society Publishing, London, 283(1832): 20160690.

Camerlengo, A. \& Demmler, M.I. 1997. Wind-driven circulation of peninsular Malaysia's eastern continental shelf. Scientia Marina, 61: 203-211.

Carr, A. 1987. New perspectives on the pelagic stage of sea turtle development. Conservation Biology, 1(2): 103-121.

Christiansen, F., Putman, N.F., Farman, R., Parker, D.M., Rice, M.R., Polovina, J.J., Balazs, G.H. \& Hays, G.C. 2016. Spatial variation in directional swimming enables juvenile sea turtles to reach and remain in productive waters. Marine Ecology Progress Series, 557: 247-259.

Collard, S.B. \& Ogren, L.H. 1990. Dispersal scenarios for pelagic post-hatchling sea turtles. Bulletin of Marine Science, 47(1): 233-243.

Condie, S.A., Mansbridge, J.V. \& Cahill, M.L. 2011. Contrasting local retention and crossshore transports of the east australian current and the leeuwin current and their relative influences on the life histories of small pelagic fishes. Deep Sea Research Part II: Topic Study in Oceanography, 58: 606-615.

Cowen, R.K. \& Sponaugle, S. 2009. Larval dispersal and marine population connectivity. Annual Review of Marine Science, 1: 443-466.

Duron-Dufrenne, M. 1987. First satellite-based tracking in the atlantic ocean of a leatherback turtle Dermochelys coriacea. Comptes rendus de l'Académie des Sciences, 304: 399-402.
Endres, C.S., Putman, N.F., Ernst, D.A., Kurth, J.A., Lohmann, C.M.F. \& Lohmann, K.J. 2016. Multimodal homing in sea turtles: modeling dual use of geomagnetic and chemical cues in islandfinding. Frontiers in Behavioral Neurosciences, 10.

Fang, W. 2002. Seasonal structures of upper layer circulation in the southern south china sea from in situ observations. Journal of Geophysical Research, 107(11): 3202.

Gaspar, P., Georges, J.Y., Fossette, S., Lenoble, A., Ferraroli, S. \& Le Maho, Y. 2006. Marine animal behaviour: neglecting ocean currents can lead us up the wrong track, in: Proceedings of the royal society b: biological sciences. the royal society publishing, London, pp. 2697-2702.

Glenn, L. 1998. The consequences of human manipulation of the coastal environment on hatchling loggerhead sea turtles (Caretta caretta), in: Proceedings of The Sixteenth Annual Symposium on Sea Turtle Biology and Conservation. NOAA Technical Memorandum NMFS-SEFSC-412, pp. 58-59.

Godley, B.J., Barbosa, C., Bruford, M., Broderick, A.C., Catry, P., Coyne, M.S., Angela, F., Hays, G.C. \& Witt, M.J. 2010. Unraveling migratory connectivity in marine turtles using multiple methods. Journal of Applied Ecology, 47: 769778.

Hamann, M., Godfrey, M.H., Seminoff, J.A., Arthur, K., Barata, P.C.R., Bjorndal, K.A., Bolten, A., Broderick, A., Campbell, L., Carreras, C., Casale, P., Chaloupka, M., Chan, K.F., Coyne, M.S., Crowder, L.B., Diex, C.E., Dutton, P.H., Epperly, S.P., FitzSimmons, N.N., Formia, A., Girondot, M., Hays, G.C., Cheng, I.J., Kaska, Y., Lewison, R., Mortimer, J.A., Nichols, W.J., Reina, R.D., Shanker, K., Spotila, J.R., Tomas, J., Wallace, B.P., Work, T.M., Zbinden, J. \& Godley, B.J. 2010. Global research priorities for sea turtles: informing management and conservation in the 21 st century. Endangered Species Research, 11(3): 245-269.

Harewood, A. \& Horrocks, J. 2008. Impacts of coastal development on hawksbill hatchling survival and swimming success during the initial offshore migration. Biological Conservation, 141(2): 394-401.

Hays, G.C. \& Marsh, R. 1997. Estimating the age of juvenile loggerhead sea turtles in the north atlantic. Canadian Journal of Zoology, 75(1): 40-46. 
Hays, G.C., Fossette, S., Kastelidis, K.A., Mariani, P. \& Schofield, G. 2010. Ontogenetic development of migration: Lagrangian drift trajectories suggest a new paradigm for sea turtles. Journal of the Royal Society Interface, 7(50): 13191327.

Hochscheid, S., Bentivegna, F., Bradhai, M.N. \& Hays, G.C. 2007. Overwintering behaviour in sea turtles: dormancy is optional. Marine Ecology Progress Series, 340: 287-298.

Joseph, J., Nishizawa, H., Arshaad, W.M., Kadir, S.A.S., Jaaman, S.A., Bali, J., Jamaludin, N.A. \& Katoh, M. 2016. Genetic stock compositions and natal origin of green turtle (Chelonia mydas) foraging at Brunei Bay. Global Ecology and Conservation, 6: 16-24.

Kok, P.H., Akhir, M.F. \& Tangang, F.T. 2015. Thermal frontal zone along the east coast of Peninsular Malaysia. Continental Shelf Research, 110: 1-15.

Lett, C., Verley, P., Mullon, C., Parada, C., Brochier, T., Penven, P. \& Blanke, B. 2008. A lagrangian tool for modelling ichthyoplankton dynamics. Environmental Modelling \& Software, 23(9): 1210-1214.

Liew, H.C., Chan, E.H., Papi, F. \& Luschi, P. 1995. Long distance migration of green turtles from Redang Island, Malaysia: The need for regional cooperation in sea turtle. In: International Congress of Chelonian Conservation. pp. 10.

Lohmann, K.J., Cain, S.D., Dodge, S.A. \& Lohmann, C.M. 2001. Regional magnetic fields as navigational markers for sea turtles. Science, 294(5541): 364-366.

Luschi, P., Papi, F., Liew, H.C., Chan, E.H. \& Bonadonna, F. 1996. Long-distance migration and homing after displacement in the green turtle (Chelonia mydas): a satellite tracking study. Journal of Comparative Physiology A, 178(4): 447-452.

Mansfield, K.L., Wyneken, J., Porter, W.P. \& Luo, J. 2014. First satellite tracks of neonate sea turtles redefine the 'lost years' oceanic niche, in: Proceedings of The Royal Society b. The Royal Society Publishing, London, 281(1781): 20133039.

Mansfield, K.L., Mendilaharsu, M.L., Putman, N.F., dei Marcovaldi, M.A., Sacco, A.E., Lopez, G., Pires, T. \& Swimmer, Y. 2017. First satellite tracks of south Atlantic Sea turtle 'lost years': seasonal variation in trans-equatorial movement, in: Proceedings of The Royal Society b. The Royal Society Publishing, London, 284(1868): 20171730.
Monzón-Argüello, C., López-Jurado, L.F., Rico, C., Marco, A., López, P., Hays, G.C. \& Lee, P.L. 2010. Evidence from genetic and lagrangian drifter data for transatlantic transport of small juvenile green turtles. Journal of Biogeography, 37(9): 1752-1766.

Moon, D.Y., MacKenzie, D.S. \& Owens, D.W. 1997. simulated hibernation of sea turtles in the laboratory: i. feeding, breathing frequency, blood ph, and blood gases. Journal of Experimental Zoology, 278: 372-380.

National Oceanic and Atmospheric Administration. 2018. What is upwelling? [WWW Document]. URL https://oceanservice.noaa.gov/facts/ upwelling.html (accessed 1.23.20).

Nishizawa, H., Joseph, J. \& Chong, Y.K. 2016. Spatio-temporal patterns of mitochondrial DNA variation in hawksbill turtles (Eretmochelys imbricata) in Southeast Asia. Journal of Experimental Marine Biology and Ecology, 474: 164170.

Okuyama, J., Abe, O., Nishizawa, H., Kobayashi, M., Yoseda, K. \& Arai, N. 2009. Ontogeny of the dispersal migration of green turtle (Chelonia mydas) hatchlings. Journal of Experimental Marine Biology and Ecology, 379: 43-50.

Okuyama, J., Kitagawa, T., Zenimoto, K., Kimura, S., Arai, N., Sasai, Y. \& Sasaki, H. 2011. TransPacific dispersal of loggerhead turtle hatchlings inferred from numerical simulation modeling. Marine Biology, 158: 2055-2063.

Oñate Casado, J. 2018. Effect of Tidal Surface Currents on The Offshore Hatchlings Dispersion. A Comparative Study Among Green and Hawksbill Turtles on Chagar Hutang Turtle Sanctuary, Pulau Redang, Malaysia (Master). University of Florence.

Ooi, S.H., Samah, A.A. \& Braesicke, P. 2013. Primary productivity and its variability in the equatorial south china sea during the northeast monsoon. Atmospheric Chemistry and Physics Discussions, 13(8): 21573-21608.

Pagán, F. 2003. Modeling Egg and Larval Dispersal in the Nearshore Waters of Southwestern Puerto Rico (Ph.D). University of Puerto Rico.

Papi, F., Liew, H.C., Luschi, P. \& Chan, E.H. 1995. Long-range migratory travel of a green turtle tracked by satellite: evidence for navigational ability in the open sea. Marine Biology, 122(2): 171-175.

Polovina, J.J., Kobayashi, D.R., Parker, D.M., Seki, M.P. \& Balazs, G.H. 2000. Turtles on the edge: movement of loggerhead turtles (Caretta caretta) along oceanic, fronts, spanning longline fishing grounds in the central North Pacific, 1997-1998. Fisheries Oceanography. 9: 71-82. 
Proietti, M.C., Reisser, J., Marins, L.F., Marcovaldi, M.A., Soares, L.S., Monteiro, D.S., Wijeratne, S., Pattiaratchi, C. \& Secchi, E.R. 2014. Hawksbill $\times$ loggerhead sea turtle hybrids at Bahia, Brazil: where do their offspring go? Peer J, 2: 255.

Putman, N.F. \& He, R. 2013. Tracking the longdistance dispersal of marine organisms: sensitivity to ocean model resolution. Journal of the Royal Society Interface, 10(81): 20120979.

Putman, N.F. \& Mansfield, K.L. 2015. Direct evidence of swimming demonstrates active dispersal in the sea turtle "lost years". Current Biology, 25(9): 1221-1227.

Putman, N.F., Shay, T.J. \& Lohmann, K.J. 2010. Is the geographic distribution of nesting in the Kemp's ridley turtle shaped by the migratory needs of offspring? Integrative and Comparative Biology, 50: 305-314.

Putman, N.F., Scott, R., Verley, P., Marsh, R. \& Hays, G.C. 2012a. Natal site and offshore swimming influence fitness and long-distance ocean transport in young sea turtles. Marine Biology, 159: $2117-2126$.

Putman, N.F., Verley, P., Shay, T.J. \& Lohmann, K.J. 2012b. Simulating transoceanic migrations of young loggerhead sea turtles: merging magnetic navigation behavior with an ocean circulation model. Journal of Experimental Biology, 215: 1863-1870.

Putman, N.F., Verley, P., Endres, C.S. \& Lohmann, K.J. 2015. Magnetic navigation behavior and the oceanic ecology of young loggerhead sea turtles. Journal of Experimental Biology, 218(7): 1044-1050.

Putman, N.F., Lumpkin, R., Sacco, A.E. \& Mansfield, K.L. 2016. Passive drift or active swimming in marine organisms? in: Proceedings of The Royal Society b. The Royal Society Publishing, London, 283(1844): 20161689.

Robson, N.A., Hetzel, Y., Whiting, S., Wijeratne, S., Pattiaratchi, C.B., Withers, P. \& Thums, M. 2017. Use of particle tracking to determine optimal release dates and locations for rebilitated neonate sea turtles. Frontiers in Marine Science, 4: 173.

Rusli, M.U. 2016. The Energetics of Nest Escaping by Turtle Hatchlings (Ph.D), University of Queensland.

Schmidt-Nielsen, K. 1997. Animal Physiology: Adaptation and Environment. 5th Ed. Cambridge University Press. 617 pp.

Scott, R., Marsh, R. \& Hays, G.C. 2012. A little movement orientated to the geomagnetic field makes a big difference in strong flows. Marine Biology, 159: 481-488.
Scott, R., Marsh, R. \& Hays, G.C. 2014. Ontogeny of long-distance migration. Ecology, 95(10): 2840-2850.

Seney, E.E., Higgins, B.M. \& Landry Jr, A.M. 2010. Satellite transmitter attachment techniques for small juvenile sea turtles. Journal of Experimental Marine Biology and Ecology, 384(1\&2): 61-67.

Shillinger, G.L., Di Lorenzo, E., Luo, H., Bograd, S.J., Hazen, E.L., Bailey, H. \& Spotila, J.R. 2012. On the dispersal of leatherback turtle hatchlings from Mesoamerican nesting beaches, in: Proceedings of The Royal Society b. The Royal Society Publishing, London, london, pp. 23912395.

Stoneburner, D.L. 1982. Satellite telemetry of loggerhead sea turtle movement in the georgia bight. Copeia, 1982: 400-408.

Timko, R.E. \& Kolz A.L. 1982. Satellite sea turtle tracking. Marine Fish Revolution, 44: 19-24.

Werner, F.E., Cowen, R.K. \& Paris, C. 2007. Coupled biological and physical models: present capabilities and necessary developments for future studies of population connectivity. Oceanography, 20: 54-69.

Whelan, C.L. \& Wyneken, J. 2007. Estimating predation levels and site-specific survival of hatchling loggerhead seaturtles (Caretta caretta) from South Florida beaches. Copeia, 2007(3): 745-754.

Williams, S. 2012. Quantifying the energetic cost of disorientation in loggerhead. Physiology, 94: 663-665.

Witham, R. 1980. The "lost year" question in young sea turtles. American Zoologist, 20(3): 525-530.

Witherington, B. 2002. Ecology of neonate loggerhead turtles inhabiting lines of downwelling near a Gulf Stream front. Marine Biology, 140(4): 843-853.

Witherington, B., Hirama, S. \& Hardy, R. 2012. Young sea turtles of the pelagic Sargassumdominated drift community: habitat use, population density, and threats. Marine Ecology Progress Series, 463: 1-22.

Wyneken, J. \& Salmon, M. 1992. Frenzy and postfrenzy swimming activity in loggerhead, green, and leatherback hatchling sea turtles. Copeia, 478-484.

Wyneken, J., Madrak, S.V., Salmon, M. \& Foote, J. 2008. Migratory activity by hatchling loggerhead sea turtles (Caretta caretta): evidence for divergence between nesting groups. Marine Biology, 156(2): 171-178. 
